\title{
Comparative study of municipal solid waste treatment technologies using life cycle assessment method
}

\author{
*A. U. Zaman \\ Environmental Engineering and Sustainable Infrastructure, School of Architecture and Built Environment, \\ KTH, Sweden
}

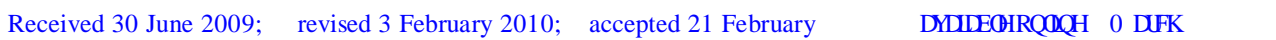

\begin{abstract}
The aim of the study is to analyze three different waste treatment technologies by life cycle assessment tool. Sanitary Landfill, Incineration and gasification-pyrolysis of the waste treatment technologies are studied in SimaPro software based on input-output materials flow. SimaPro software has been applied for analyzing environmental burden by different impact categories. All technologies are favorable to abiotic and ozone layer depletion due to energy recovery from the waste treatment facilities. Sanitary landfill has the significantly lower environmental impact among other thermal treatment while gases are used for fuel with control emission environment. However, sanitary landfill has significant impact on photochemical oxidation, global warming and acidification. Among thermal technology, pyrolysisgasification is comparatively more favorable to environment than incineration in global warming, acidification, eutrophication and eco-toxicity categories. Landfill with energy recovery facilities is environmentally favorable. However, due to large land requirement, difficult emission control system and long time span, restriction on land filling is applying more in the developed countries. Pyrolysis-gasification is more environmental friendly technology than incineration due to higher energy recovery efficiency. Life cycle assessment is an effective tool to analyze waste treatment technology based on environmental performances.
\end{abstract}

Keywords: Environmental assessment; Incineration; Pyrolysis-gasification; Sanitary landfill; Waste-to-energy

\section{INTRODUCTION}

Waste is no more treated as the valueless garbage; waste is rather considered as a resource in the present time. Resource recovery is one of the prime objectives in sustainable waste management system. Different waste treatment options are available in the current time with different waste management capacities. There is no a single technology that can solve the waste management problem (Tehrani et al., 2009). Integrated waste management system is commonly applied method in many developed countries. Integrated waste management system offers the flexibility of waste treatment option based on different waste fraction like plastic, glass, organic waste or combustible waste. Energy and resource recovery is also important and can be recovered through integrated waste management system. There are different system analysis tools (Finnveden and Moberg, 2004) that are available at the present time for the decision makers. Technology or strategy can be analyzed by the

ه*Corresponding Author Email: atique@kth.se

Tel./Fax: +4673 7525708 environmental, social or environmental point of view. Life cycle assessment (LCA) is a commonly applied tool to analyze environmental burden for waste management technology, as well as system. In this study, three different municipal solid waste (MSW) management options like pyrolysis-gasification, incineration and sanitary landfill are analyzed by life cycle assessment model using SimaPro software (version 7). In addition, for life cycle inventory analysis, CML 2 (Centre for Environmental Studies, University of Leiden) baseline (2000) method has been used. The study is done primarily to assess three different options and to analyze the environmental burden from the three technologies. Results from the comparative study would be helpful for decision-making processes to evaluate environmental performance of the technologies. However, socio-economic and applicability of the technology are also important for decision and policy making processes which are not considered in this study. Especially, considering land requirement and continuous function-ability of 
sanitary landfill and other two thermal waste treatment options would have the significant differences which influence decision-making choice while considering MSW treatment options. Different studies have already been done for MSW management options to analyze the benefits and problems associated with the processes. Some of the studies are done by Hallenbeck (1995); Consonni et al. (2005); Liamsanguan and Gheewala (2007); Parizek et al. (2008); Grieco and Poggio (2009), Psomopoulos et al. (2009), Stehlik (2009). Integrated waste management system (IWMS) is one of the effective strategies to solve waste management problems. The study has been done in the context of Sweden waste treatment system. However, the data for pyrolysis-gasification of waste has been taken from the United Kingdom's research report due to lack of local data by assuming that both Sweden and UK has similar waste content in municipal solid waste.

\section{MATERIALS AND METHODS}

MSW treatment technologies

Integrated waste management options are now been applying in most of the developed countries with resource recycle, recovery and energy generation facilities from the solid waste. Waste-to-energy (WTE) conversion is now considered as one of the optimal methods to solve the waste management problem in a sustainable way. Different mechanical biological and thermo-chemical waste-to-energy technologies are now applying for managing MSW. In this study, three different MSW technologies like 1) sanitary landfill, 2) incineration and 3) Pyrolysis/gasification are analyzed.
Brief descriptions of these three technologies are given bellow.

\section{Landfill}

"A landfill is a facility in which solid wastes are disposed in a manner which limits their impact on the environment. Landfills consist of a complex system of interrelated components and sub-systems that act together to break down and stabilize disposed wastes over time” (FCM, 2004). Landfill is very old but still one of the extensively used technologies for MWS management. Most of the landfill does not have the energy production facilities. In this study, a sanitary landfill with energy recovery system has been studied. Landfill gas are generated from the landfill site in different gas generation phases. Generally, five different phases like initial adjustment, transition phase, acid phase, methane fermentation and maturation phases are observed in waste landfill (Adapted from Farquhar and Rovers, 1973; Parker, 1983; Pohland, 1987, 1991). A typical WTE generation by landfill process has shown in Fig. 1.

\section{Incineration}

Incineration is a thermal waste treatment process where raw or unprocessed waste can be used as feedstock. The incineration process takes place in the presence of sufficient quantity of air to oxidize the feedstock (fuel). Waste is combusted in the temperature of $850^{\circ} \mathrm{C}$ and in this stage waste converted to carbon dioxide, water and non-combustible materials with solid residue state called incinerator bottom ash (IBA) that always contains a small amount of residual carbon (DEFRA, 2007).

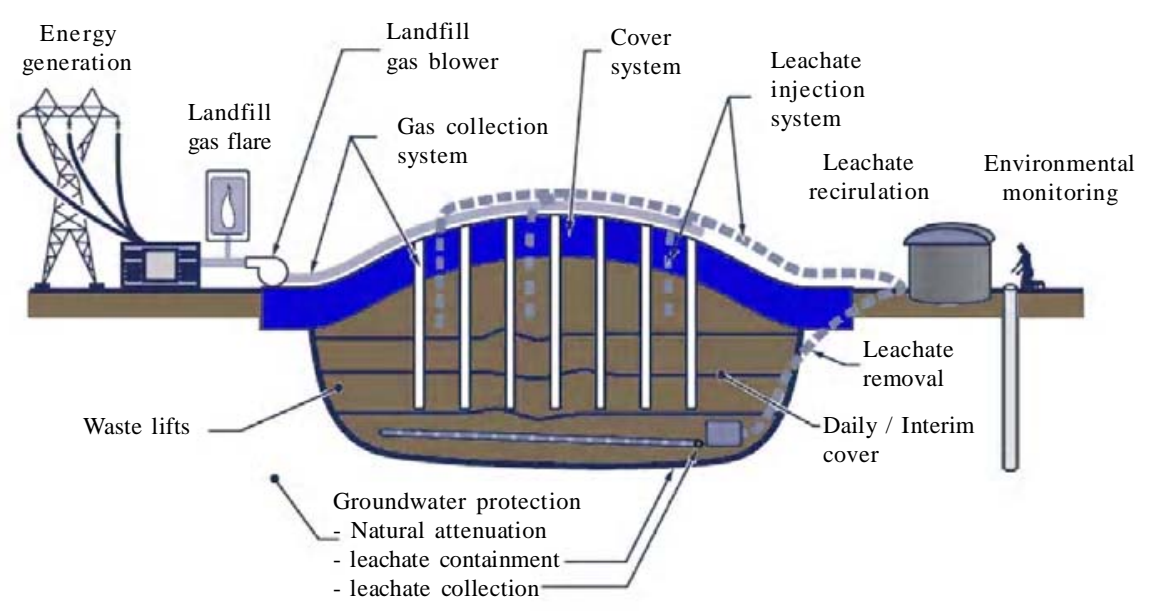

Fig. 1: Principal technical elements of a landfill (FCM, 2004) 


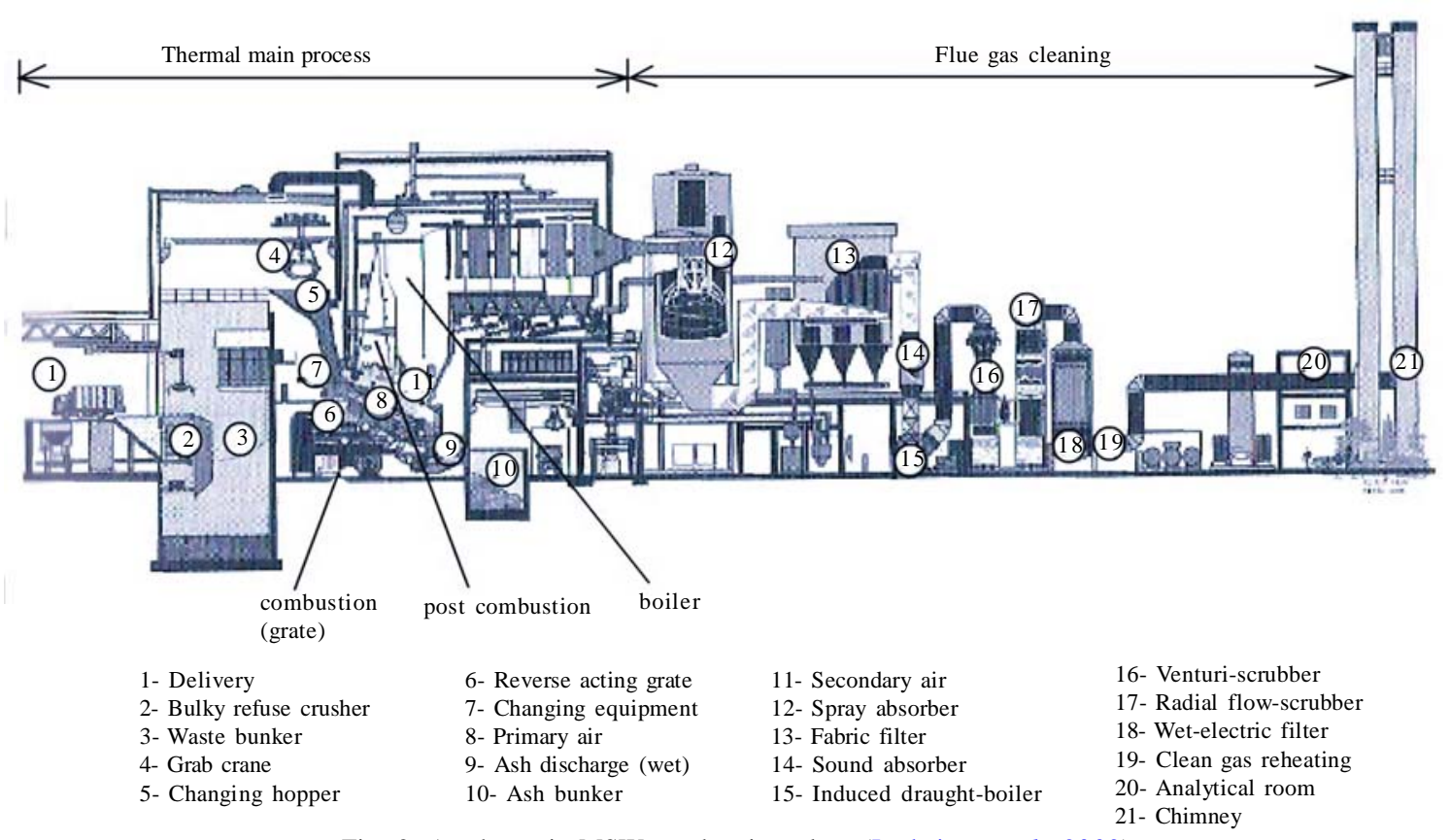

Fig. 2: A schematic MSW combustion plant (Ludwing et al., 2002)

Fig. 2 shows the schematic diagram of MSW combustion plant where wastes are delivered as feed stock to the pre-combustion (grate) and during post combustion, gas and slug or ashes are produced. Then, in the next phases flue gas is cleaned by water absorber or different filtering methods. Finally, the clean gas is emitted through the chimney to the air. Thermal conversation of waste to energy is now very much applied technology for waste management system due to the generation of heat and energy from the waste stream.

\section{Pyrolysis-gasification}

Pyrolysis is the thermal degradation of waste in the absence of air to produce gas (often termed syngas), liquid (pyrolysis oil) or solid (char, mainly ash and carbon). Pyrolysis generally takes place between 400$1000^{\circ} \mathrm{C}$. Gasification takes place at higher temperatures than pyrolysis $\left(1,000-1,400^{\circ} \mathrm{C}\right)$ in a controlled amount of oxygen (NSCA, 2002). The gaseous product contains $\mathrm{CO}_{2}, \mathrm{CO}, \mathrm{H}_{2}, \mathrm{CH}_{4}, \mathrm{H}_{2} \mathrm{O}$, trace amounts of higher hydrocarbons (Bridgwater, 1994). MSW pyrolysis and in particular gasification is obviously very attractive to reduce and avoid corrosion and emissions by retaining alkali and heavy metals (Malkow, 2004). There would be a net reduction in the emission of the sulphur di-oxide and particulates from the Pyrolysis/Gasification processes. However, the emission of oxides of nitrogen,
VOCs and dioxins might be similar with the other thermal waste treatment technology (DEFRA, 2004). Fig. 3 shows the typical flow diagram of the pyrolysisgasification processes.

\section{Life cycle assessment}

Life cycle environmental assessment tool is one of the effective and principal decision support tools (Christensen et al., 2007) to assess the flow dynamics of the resources. LCA can give us the idea on environmental burdens per functional unit (kg/ton) of waste generated (Ekvall et al., 2007). Many research works have already been done on LCA all over the world as a decision making tool (Gheewala and Liamsanguan, 2008) for assessing (Bilitewski and Winkler, 2007) waste technology (Ekvall and Finnveden, 2000) models (Björklund, 2000); (Diaz and Warith, 2006) methods (Matsuto, 2002) and strategies (Barton and Patel, 1996; Björklund and Finnveden, 2007; Pennington and Koneczny, 2007; Cherubini et al., 2008) for MSW management. All these study have analyzed waste management options through life cycle perspectives. This study has been done by considering inflow, outflow data, emissions and resource recovery through electricity and heat recovery from the system. The study is analyzed three different waste treatment technologies that can manage all type of waste fraction. 


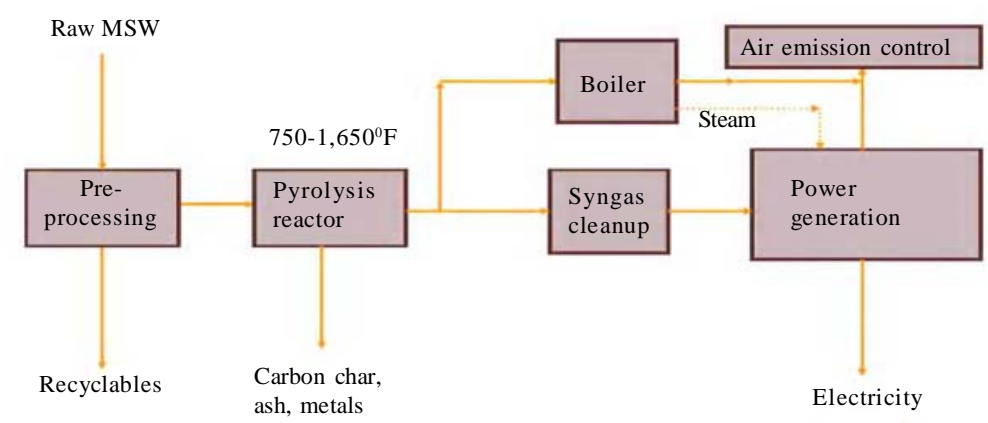

Fig. 3: Typical pyrolysis/gasification system of MSW (Halton EFW Business Case, 2007)

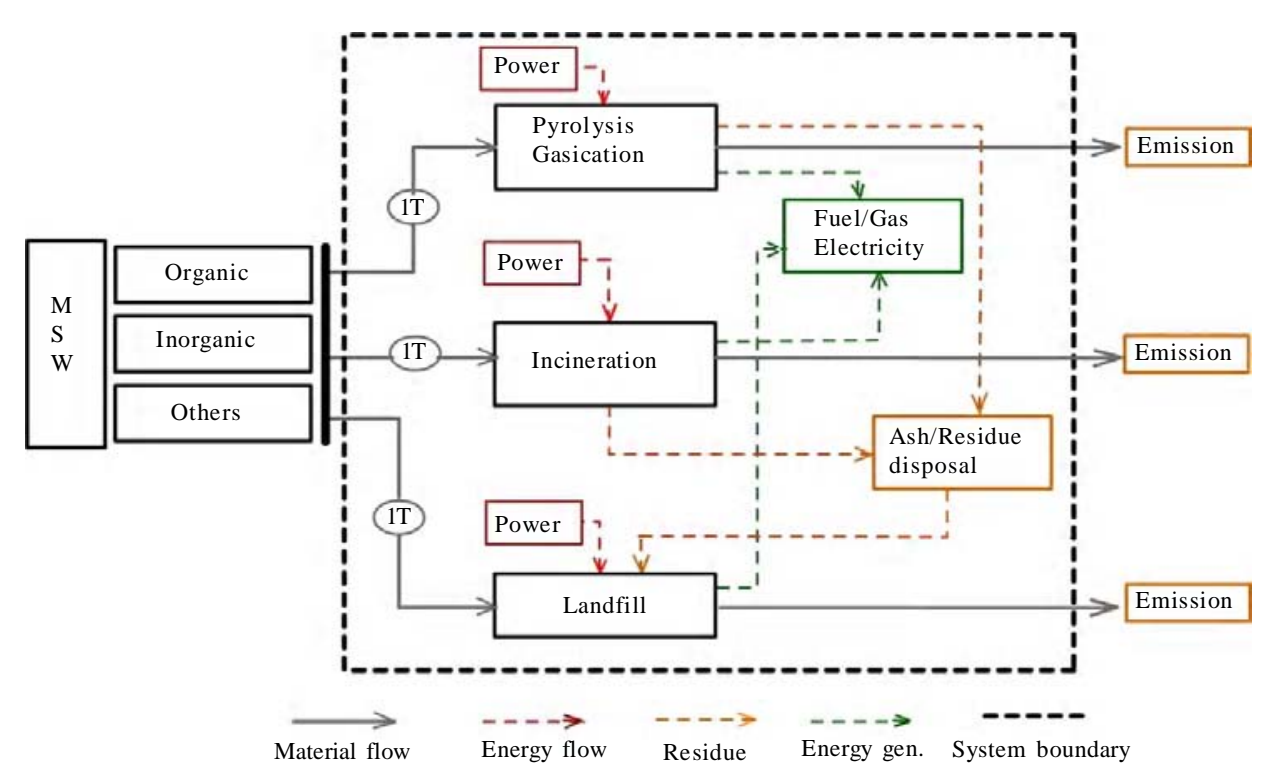

Fig. 4: System boundary for different MSW treatment processes

\section{Aim and scope}

Goal of the study is to develop a LCA model and compare three different MSW treatment options. The study has been carried out by SimaPro (7.0 version) software, life cycle impact assessment has been done by considering CML 2 baseline (2000) method. Waste management technologies are analyzed by ten different impact categories like abiotic depletion, acidification, eutrophication, global warming, ozone layer depletion, human toxicity, fresh water ecotoxicity, marine ecotoxicity, terrestrial ecotoxicity and photochemical oxidation. Functional unit of the study has been set as one ton of waste mass. Thus, all input and output flows in the model are considered as a reference flow of one ton of MSW treatment for WTE generation. A comparative LCA study has been done in this study. Therefore, average country mix (Sweden) data have been considered for the LCA model while allocating avoiding product. Allocations of the resources have been done based on the system expansion. Fig. 4 shows the system boundary of the WTE options. Waste is considered as a mixture of compostable or organic, 
Int. J. Environ. Sci. Tech., 7 (2), 225-234, Spring 2010

Table 1: Input-output (energy and residue) in different MSW treatment processes

\begin{tabular}{|c|c|c|c|}
\hline Input/output & Pyrolysis-Gasification & Incineration & Landfill \\
\hline Start-up energy $(\mathrm{kWh} / \mathrm{T})$ & $339.3(3)$ & $77.8(1)$ & $14.3(1)+(5)^{*}$ \\
\hline Energy generated $(\mathrm{kWh} / \mathrm{T})$ & $685(4)$ & $544(4)$ & $217.3(1)+(2)$ \\
\hline Solid residue $(\mathrm{kg} / \mathrm{T})$ & $120(2)$ & $180(2)$ & --- \\
\hline
\end{tabular}

Sources: 1) Finnveden et al., (2000), 2) DEFRA (2004), 3) Khoo (2009), 4) Circeo (2009), 5) Cherubini et al. (2008), *Diesel fuel normalized to the energy unit $\mathrm{kWh} / \mathrm{ton}$

Table 2: Emissions to air from waste management facilities (grams per ton of MSW)

\begin{tabular}{|c|c|c|c|}
\hline \multicolumn{4}{|c|}{ Emissions to the air from different treatment processes } \\
\hline Substance & Pyrolysis-Gasification (gm/T) & Incineration $(\mathrm{gm} / \mathrm{T})$ & Landfill (gm/T) \\
\hline Particulates & 12 & 38 & 5,3 \\
\hline Hydrogen chloride & 32 & 58 & 3 \\
\hline Hydrogen fluoride & 0.34 & 1 & 3 \\
\hline VOCs & 11 & 8 & 6,4 \\
\hline Chloroethene & Not likely to be emitted & Not likely to be emitted & 0,28 \\
\hline Chlorobenzene & Not likely to be emitted & Not likely to be emitted & 0,59 \\
\hline Tetrachloroethene & Not likely to be emitted & Not likely to be emitted & 0,98 \\
\hline Benzene & Not likely to be emitted & Not likely to be emitted & 0,00006 \\
\hline Methane & Not likely to be emitted & Not likely to be emitted & 20,000 \\
\hline Cadmium & 0.0069 & 0.005 & 0,071 \\
\hline Polychlorinated biphenyls & No data & 0.0001 & No data \\
\hline Carbon dioxide & $10,00,000 *$ & $10,00,000$ & $3,00,000$ \\
\hline Carbon monoxide & 100 & No data & --- \\
\hline
\end{tabular}

Source: DEFRA (2004), ${ }^{*} \mathrm{CO}_{2}$ assumed same as incineration due to same carbon content

inorganic and other types of waste fractions. Within the system boundary, all inputs to the system like 1 ton of MSW and energy requirement for the processes and all outputs like emission to the air waster or soil and final disposal and electricity generation from the systems have been considered.

\section{Assumptions}

Following assumptions have been made for the LCA model:

- Transport distance of waste for all processes system assumed as same and that's why transportation has been omitted from the system boundary;

- Electricity that produced in the processes is avoided as the average Swedish national electricity production.

\section{Life cycle inventory and data analysis}

Life cycle inventory of the LCA model has been made primarily based on the literature, report and publications. Important papers are Bridgwater (1994); Finnveden et al., (2000); NSCA (2002); Feo et al., (2003); DEFRA (2004); Halton EFW Business Case (2007); Cherubini et al. (2008); Circeo (2009); Khoo (2009). Data emission from the WTE system is shown in the following Table 1.

In LCA model of Pyrolysis-Gasification, the input data have taken as resource (one ton MSW), energy (electricity kWh/ton of MSW), emission (gm/T) to air, soil or waster, energy generation (kWh/ton of MSW) and final residue (kg/ton) produced by the facilities. Table 2 shows the emission rate emitted by the facilities during treated one ton of MSW.

Since, carbon content in waste is constant, therefore, for $\mathrm{P}-\mathrm{G}$ process carbon dioxide emission was assumed same as incineration of municipal solid waste. Model however, developed based on the fossil carbon content (39.5\%) in the total carbon emission.

Table 3 shows the water emission from the landfill and here surface water and ground water emission are considering as total waster emission. 
Life cycle impact assessment (LCIA)

Life cycle impact assessment of the WTE technologies has been done the CML 2 baseline (2000) method. Environmental impacts from the three different MSW treatment facilities are analyzed based on ten different impact categories in CML methods. Impact categories in CML method are abiotic depletion, acidification, eutrophication, global warming potential, ozone layer depletion, human toxicity, fresh aquatic ecotoxicity, marine aquatic ecotoxicity, terrestrial ecotoxicity and photochemical oxidation. Characterization values of the each impact categories are analyzed; normalization of the impact category based on global value. Normalization values are taken as the world 1990 value in the LCA model and value are given in Table 4.

\section{RESULTS AND DISCUSSION}

Comparative LCA model of pyrolysis-gasification, Incineration and Landfill has been developed where impact of transportation system is not considered for

Table 3: Emission to the waste from the landfill treatment process

\begin{tabular}{lc}
\hline Substances & $\begin{array}{c}\text { Emission to water (surface and } \\
\text { ground) from landfill (gm/T)* }\end{array}$ \\
\hline Aniline & 0.00000262 \\
Chloride & 30 \\
Cyanide & 0.0013 \\
Fluoride & 0164 \\
Nitrogen (Total) & 9.4 \\
Phenols & 0.0000077 \\
Phosphorus & 0.076 \\
Toluene & 0.00019 \\
Arsenic & 0.000061 \\
Chromium & 0.0009 \\
Copper & 0.00014 \\
Lead & 0.0012 \\
Nickel & 0.0012 \\
Zinc & 0.00109 \\
\hline Source: DEFRA (2004), * Total emission of water has been counted by \\
adding up the surface and groundwater emission.
\end{tabular}

any of the processes. Table 5 shows the characterization value of different impact categories. From the characterization table, all of the MSW treatment facility has the positive environmental impact on abiotic and ozone layer depletion categories due to the electricity generation by the processes. Landfill has the higher safety value in abiotic depletion and incineration has the higher value in ozone layer depletion category than the pyrolysis-gasification process. From the comparative study, incineration has the higher environmental impact than the PyrolysisGasification in the acidification, eutrophication, global warming, human toxicity, aquatic toxicity categories; however, pyrolysis-gasification has the higher potential environmental impact in terrestrial ecotoxicity and photochemical oxidation categories. Incineration has the highest global warming potential among the three facilities and pyrolysis-gasification has the lower GWP however, carbon emission assumed same as incineration and this was because of lower final residue production. Landfill has the highest photochemical potential among the three and incineration has the least photochemical oxidation potential. Fig. 5 shows the characterization graph of the comparative LCA model. Normalization graph (Fig. 6 and Table 6) shows that

Table 4: Normalization value used in CML 2 method

\begin{tabular}{llc}
\hline Impact Categories & Unit & World, 1990 \\
\hline Abiotic depletion & $\mathrm{kg} \mathrm{Sb}$ eq & $6.32 \mathrm{E}-12$ \\
Acidification & $\mathrm{kg} \mathrm{SO}_{2}$ eq & $3.09 \mathrm{E}-12$ \\
Eutrophication & $\mathrm{kg} \mathrm{PO}_{4}---$ eq & $7.53 \mathrm{E}-12$ \\
Global warming potential & $\mathrm{kg} \mathrm{CO}$ eq & $2.27 \mathrm{E}-14$ \\
(GWP100) & & \\
Ozone layer depletion & $\mathrm{kg} \mathrm{CFC-11} \mathrm{eq}$ & $8.76 \mathrm{E}-10$ \\
Human toxicity & $\mathrm{kg} \mathrm{1,4-DB} \mathrm{eq}$ & $1.67 \mathrm{E}-14$ \\
Fresh water aquatic ecotox. & $\mathrm{kg} \mathrm{1,4-DB} \mathrm{eq}$ & $4.83 \mathrm{E}-13$ \\
Marine aquatic ecotoxicity & $\mathrm{kg} \mathrm{1,4-DB} \mathrm{eq}$ & $1.32 \mathrm{E}-15$ \\
Terrestrial ecotoxicity & $\mathrm{kg} \mathrm{1,4-DB} \mathrm{eq}$ & $3.79 \mathrm{E}-12$ \\
Photochemical oxidation & $\mathrm{kg} \mathrm{C} \mathrm{H}_{4}$ & $5.59 \mathrm{E}-12$ \\
\hline
\end{tabular}

Source: Pré Consultants (2008)

Table 5: Comparative characterization model for treatment facilities

\begin{tabular}{|c|c|c|c|c|}
\hline Impact category & Unit & Pyrolysis-gasification & Incineration & Landfill \\
\hline Abiotic depletion & kg Sb eq & -0.04597 & -0.04563 & -0.09049 \\
\hline Acidification & $\mathrm{kg} \mathrm{SO}_{2} \mathrm{eq}$ & 0.24779 & 0.584653 & 0.243961 \\
\hline Eutrophication & $\mathrm{kg} \mathrm{PO}_{4}---\mathrm{eq}$ & 1.129403 & 1.751102 & 0.088294 \\
\hline Ozone layer depletion (ODP) & kg CFC-11 eq & $-1.4 \mathrm{E}-05$ & $-1.9 \mathrm{E}-05$ & $-9.6 E-06$ \\
\hline Human toxicity & kg 1,4-DB eq & 805.5721 & 1178.666 & 8.149164 \\
\hline Fresh water aquatic ecotoxicity & kg 1,4-DB eq & 215.3661 & 323.0821 & -0.25392 \\
\hline Terrestrial ecotoxicity & kg 1,4-DB eq & 2.507963 & 0.703079 & 0.009382 \\
\hline Photochemical oxidation & $\mathrm{kg} \mathrm{C}_{2} \mathrm{H}_{4}$ & -0.00244 & -0.00778 & 0.116526 \\
\hline
\end{tabular}




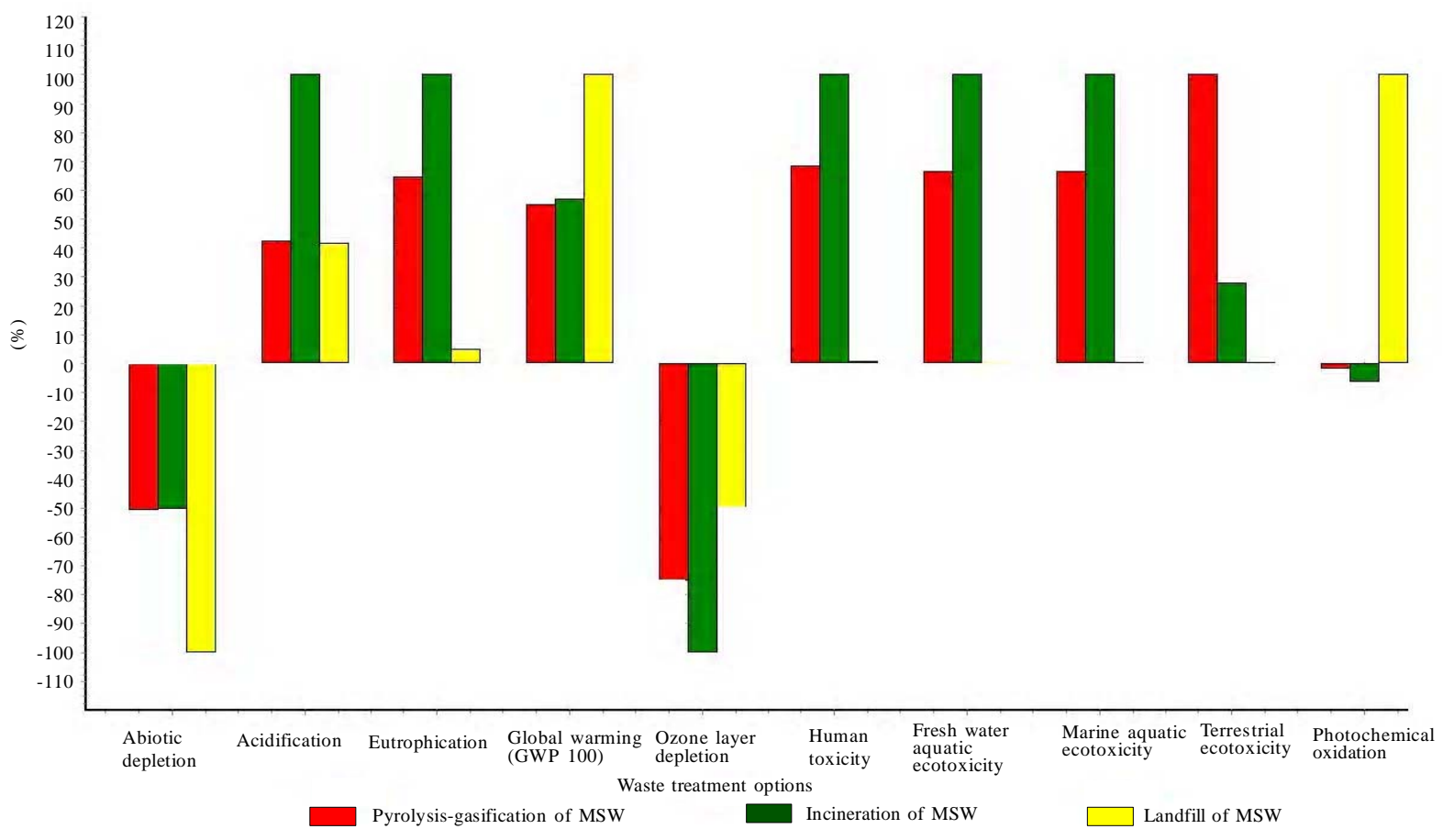

Comparing 1E3 kg 'Pyrolysis-gasification of MSW', 1E3 kg 'Incineration of MSW' and 1E3 'Landfill of MSW'; Method: CML 2baseline 2000 V2.04 / World, 1990 / characterization

Fig. 5: Comparative LCA characterization graph for different waste treatment options

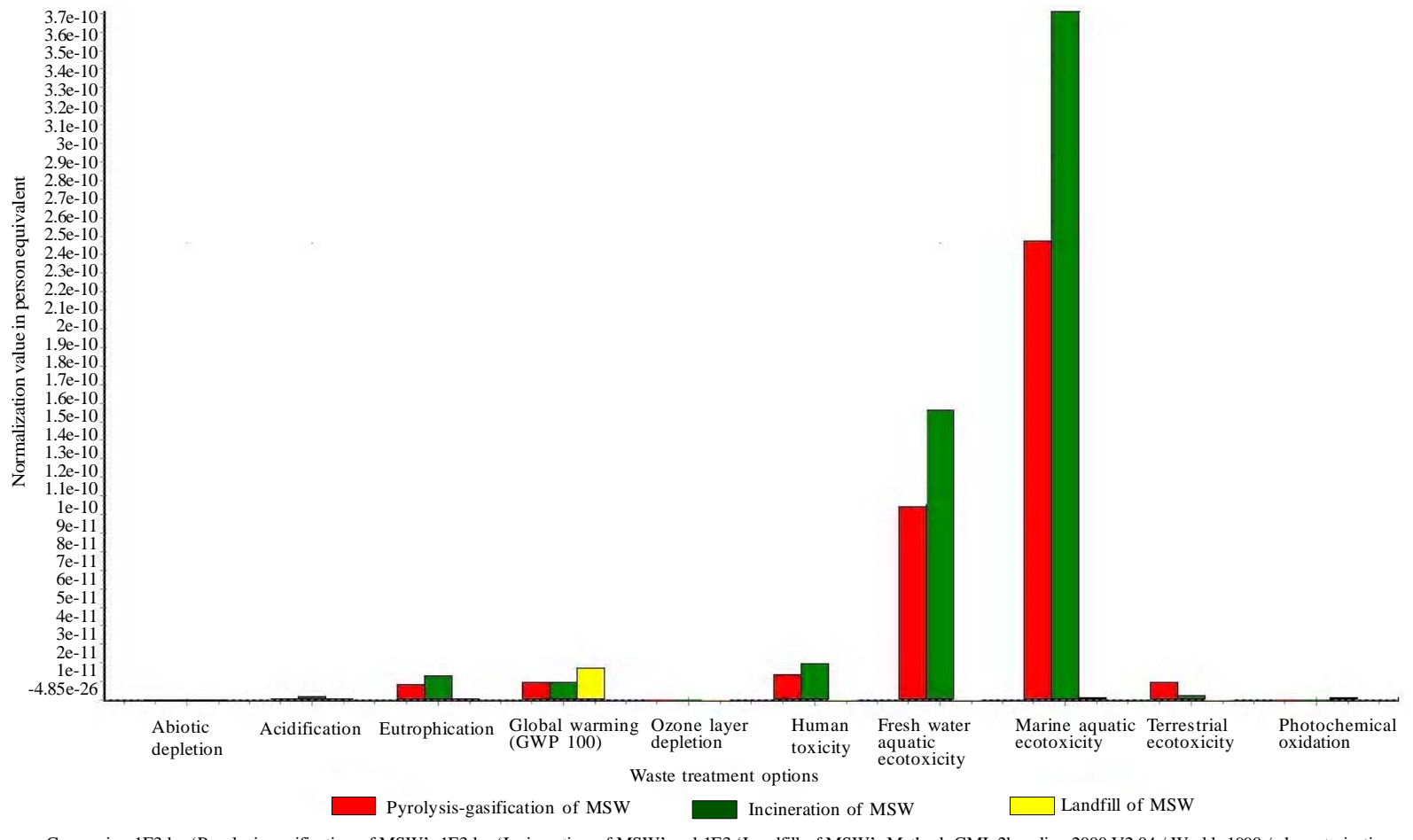

Comparing 1E3 kg 'Pyrolysis-gasification of MSW', 1E3 kg 'Incineration of MSW' and 1E3 'Landfill of MSW'; Method: CML 2baseline 2000 V2.04 / World, 1990 / characterization

Fig. 6: Comparative normalization graph for different MSW treatment options 
Municipal solid waste treatment technologies through LCA

Table 6: Normalization value of the different impact categories

\begin{tabular}{|c|c|c|c|c|}
\hline Impact category & Unit & Pyrolysis-gasification & Incineration & Landfill \\
\hline Abiotic depletion & kg Sb eq & $-2.9 \mathrm{E}-13$ & $-2.9 \mathrm{E}-13$ & $-5.7 \mathrm{E}-13$ \\
\hline Acidification & $\mathrm{kg} \mathrm{SO}_{2}$ eq & 7.66E-13 & $1.81 \mathrm{E}-12$ & $7.54 \mathrm{E}-13$ \\
\hline Eutrophication & $\mathrm{kg} \mathrm{PO}_{4}^{-3} \mathrm{eq}$ & 8.5E-12 & 1.32E-11 & $6.65 \mathrm{E}-13$ \\
\hline Ozone layer depletion (ODP) & kg CFC-11 eq & $-1.3 \mathrm{E}-14$ & $-1.7 \mathrm{E}-14$ & $-8.4 \mathrm{E}-15$ \\
\hline Human toxicity & kg 1,4-DB eq & $1.35 \mathrm{E}-11$ & $1.97 \mathrm{E}-11$ & $1.36 \mathrm{E}-13$ \\
\hline Fresh water aquatic ecotoxicity & $\operatorname{kg} 1,4-\mathrm{DB}$ eq & $1.04 \mathrm{E}-10$ & $1.56 \mathrm{E}-10$ & $-1.2 \mathrm{E}-13$ \\
\hline Photochemical oxidation & $\mathrm{kg} \mathrm{C}_{2} \mathrm{H}_{4}$ & $-2.3 \mathrm{E}-14$ & $-7.5 \mathrm{E}-14$ & $1.12 \mathrm{E}-12$ \\
\hline
\end{tabular}

marine aquatic, fresh water aquatic potential and global warming potential are the most significant impact categories for MSW treatment by these three facilities considering regional impact values. Normalization value shows that incineration has the higher environmental impact in marine aquatic, fresh water aquatic potential, global warming potential, human and eitrophication categories than the pyrolysisgasification processes. However, pyrolysisgasification has the higher environmental impact in terrestrial ecotoxicity than the incineration processes. From the inventory analysis of the impact categories, vanadium, ion, selenium, nickel ion and copper ion are the prime pollutants emitted through waste and leachate and hydrogen fluoride, benzene, carbon dioxide carbon monoxide, methane sulphur dioxide phosphate nitrogen oxide are the primary pollutants emitted to the atmosphere from the waste treatment facilities. Mercury, nickel, cadmium, hydrogen fluoride are the leading pollutants that emitted from the MSW treatment processes through air emission and cause the terrestrial ecotoxicity. Disposal of the final residue are founded as one of the most environmental impact causing phase of waste management system and vanadium, selenium, nickel copper, antimony are the leading pollutant which mainly pollutes through water and cause aquatic depletion and human toxicity. Carbon monoxide, carbon dioxide and methane have the global warming potentials and photochemical oxidation, in waste management system mainly transportation of waste, processes, and disposal have the significant global warming potential (GWP). Pollutants though the water emissions are mainly cause eutrophication.

Global warming, acidification and ozone layer depletion are the important impact categories considering current environmental importance. Present climate change impact acts as one of the main driving forces for sustainable decision making process. Both incineration and sanitary landfill has the highest global warming potential due to $\mathrm{CO}_{2}$ and methane emission to the atmosphere. For landfill, methane emission control of the landfill site is very difficult and costly processes. Incineration uses air for the thermal process and produce large amount of syngas during waste treatment process which is also produce large amount of $\mathrm{CO}_{2}$. Incineration has highest acidification impact among the three due to SOx and NOx emission to the air. However, incineration is significantly environmental favorable to the ozone layer depletion among the three treatment options. In photochemical oxidation, landfill has highest impact among all the technologies. However, global leading impact categories (global warming or acidification) have moderately lower impact value in the normalization of LCA model. Normalization graph shows that, aquatic depletion, human toxicity occurred more from the waste treatment technologies than the other impact categories. Inventory of the model show that, residue disposal to the landfill is mainly causes aquatic depletion through ground and surface water pollution. Heavy metals pollute the environment significantly from all of the technology due to manage final residue. Landfill and Incineration technologies are very old and extensively used technology. Pyrolysisgasification is an emerging technology for municipal solid waste treatment. Therefore, comparing all these technologies through a LCA model; it is important to consider the applicability and problem solving capacity of the individual technology. Sanitary landfill found environmental favorable among the three, however, land requirement, economic, use perspective (single) and life span (around 100 years or more), landfill is not favorable in the long term perspective. That is the one of the reason of banning of landfill for different waste categories in many developed countries. On the other hand, pyrolysis-gasification is an emerging technology with high electricity production capacity from the waste. 
The process is also continuous and has the option of rapid improvement in future. These factors that have been discussed before are the influential factors for the decision-making process for waste management technology selection.

\section{Uncertainty and limitations of the results}

Modern sanitary landfill with flare gas collection system for electricity generation facility has been considered for the comparison which might not be common for all countries. Sanitary landfill is more environmental friendly however; ordinary landfill has significantly high impact than the other technology. The study is done based on the process LCA analysis which is not based on waste fraction. Because assumption is made that 1 ton of waste is treated by the three different technologies and based on the emissions and energy production environmental performance of the technology is analyzed in the study. Maturity of the technology is a vital point while comparing different technologies, however, this comparative study showed the environmental burden and benefits based on the real time scale with different development level of technology. Therefore, the study did not rank any technology based on the analysis.

\section{CONCLUSION}

Different waste treatment options have different type of impacts; however, environmental soundness of the technology should be accounted in the long time perspective. Pyrolysis-gasification has found one of the emerging technologies which have lower environmental impact than the incineration process. Sanitary landfill with energy generation has the least environmental impact among the three waste treatment technologies. However, due to the socio-economic and environmental perspective landfill is not favorable waste treatment option. Disposal of final residue is one of the prime environmental concerns in thermal waste treatment processes.

\section{REFERENCES}

Barton, J. R.; Patel, V. S., (1996). Life cycle assessment for waste management. Waste Manage., 16 (1-3), 35-50 (16 pages).

Bilitewski, B.; Winkler, J., (2007). Comparative evaluation of life cycle assessment models for solid waste management. Waste Manage., 27(8), 1021-1031 (11 pages).

Björklund, A.; Finnveden, G., (2007). Life cycle assessment of a national policy proposal - The case of a Swedish waste incineration tax. Waste Manage., 27 (8), 1046-1058 (13 pages).
Björklund, A., (2000). Environmental systems analysis of waste management: Experiences from applications of the ORWARE model, P.hD. Thesis, Division of Industrial Ecology. Royal Institute of Technology, Stockholm.

Bridgwater, A. V., (1994). Catalysis in thermal biomass conversion. Appl. Catal. A., 116 (1-2), 5-47 (43 pages).

Cherubini, F.; Silvia Bargigli, S.; Sergio Ulgiati S., (2008). Life cycle assessment (LCA) of waste management strategies: Landfilling, sorting plant and incineration. Energy, 34 (12), 2116-2123 (8 pages).

Christensen, T. H.; Bhander, G.; Lindvall, H.; Larsen, A. W.; Fruergaard, T.; Anders, D.; Manfredi, S.; Boldrin, A.; Riber, C.; Hauschild, M., (2007). Experience with the use of LCAmodelling (EASEWASTE) in waste management. Waste Manage. Res., 25 (3), 257-262 (6 pages).

Circeo, L. J., (2009). Plasma arc gasification of municipal solid waste, plasma applications research program, Georgia Techology Research Institute (presentation slides), Available on: http://www.energy.ca.gov/proceedings/2008-ALT-1/ documents/2009-02-17_workshop/presentations/ Louis_Circeo-Georgia_Tech_Research_Institute.pdf

Consonni, S.; Giugliano, M.; Grosso, M., (2005). Alternative strategies for energy recovery from municipal solid waste, Part A: Mass and energy balances. Waste Manage., 25 (2), 123-135 (13 pages).

DEFRA., (2004). Department for Environment, Food and Rural Affairs. Review of environmental and health effects of waste mangement: Municipal solid waste and similar wastes, accomplished by Enviros Consulting Ltd. and University of Birmingham with Risk and Policy Analysts Ltd., Open University and Maggie Thurgood.

DEFRA., (2007). Department for Environment, Food and Rural Affairs. Incineration of municipal solid waste, waste management technology brief, the new technologies work stream of the Defra Waste Implementation Programme.

Diaz, R.; Warith, M., (2006). Life-cycle assessment of municipal solid wastes: Development of the WASTED model. Waste Manage., 26 (8), 886-901 (16 pages).

Ekvall, T.; Assefa, G.; Björklund, A.; Eriksson, O.; Finnveden, G., (2007). What life-cycle assessment does and does not do in assessments of waste management, Waste Manage., 27 (8), 989-996 (8 pages).

Ekvall T.; Finnveden G., (2000). The application of life cycle assessment to integrated solid waste management, Part 2: Perspectives on energy and material recovery from paper. Trans. IChemE., 78 (4), 288-294 (7 pages).

Farquhar, C. J.; Rovers, F. A., (1973). Gas production during refuse decomposition. Water Air Soil Pollut., 2 (4) 483-495 (13 pages).

FCM., (2004). Solid waste as a resource, review of waste technologies, 111. Federation of Canadian Municipalities. Available on: http://www.sustainablecommunities.ca/files/ Capacity_Building__Waste/SW_Guide_Technology.pdf

Feo, G. D.; Belgiorno, V.; Rocca, C. D.; Napoli R. M. A., (2003). Energy from gasification of solid wastes. Waste Manage., 23 (1), 1-15 (15 pages).

Finnveden, G.; Johansson, J.; Lind, P.; Moberg, A., (2000). Life cycle assessments of energy from solid waste, project report of "Future oriented life cycle assessments of energy from solid waste" project, fms report.

Finnveden, G.; Moberg, A., (2004). Environmental system analysis tools, an overview. J. Clean. Produt., 13 (12), 11651173 (9 pages). 
Gheewala, S. H.; Liamsanguan C., (2008). LCA: A decision support tool for environmental assessment of MSW management systems. J. Environ. Manage., 87 (1), 132138 ( 7 pages)

Grieco, E.; Poggio, A., (2009). Simulation of the influence of flue gas cleaning system on the energetic efficiency of a waste-to-energy plant. Appl. Energ., 86 (9), 1517-1523 (7 pages).

Hallenbeck, W, H., (1995). Health impact of a proposed waste to energy facility in Illinois. Bull. Environ. Contam. Toxicol., 54 (3), 342-348 (7 pages).

Halton EFW Business Case, (2007). The regional municipality of Halton, Step 1B: EFW Technology Overview.

Khoo, H. H., (2009). Life cycle impact assessment of various waste conversion technologies. Waste Manage., 29 (6), 1892-1900 (9 pages).

Liamsanguan, C.; Gheewala, S., (2007). Environmental assessment of energy production from municipal solid waste incineration. Int. J. LCA., 12 (7) 529-536 (8 pages).

Ludwing, C.; Hellweg, S.; Stucki., S., (2002). Municipal solid waste management; strategies and technologies for sustainable solutions, Springer.

Malkow, T., (2004). Novel and innovative pyrolysis and gasification technologies for energy efficient and environmentally sound MSW disposal. Waste Manage., 24 (1), 53-79 (26 pages).

Matsuto, T., (2002). Life cycle assessment of municipal solid waste management-Cost, energy consumption and $\mathrm{CO}_{2}$ emission, Proceedings of International Symposium and Workshop on Environmental Pollution Control and Waste Management 7-10 January 2002, Tunis (EPCOWM'2002), 243-248.

NSCA, (2002). Comparison of emissions from waste management options. National Society for Clean Air and Environmental Protection.

Parizek, T.; Bebar, L.; Stehlik, P., (2008). Persistent pollutants emission abatement in waste-to-energy systems. Clean Tech. Environ. Policy, 10 (2), 147-153 (7 pages).

Parker, A., (1983). Behaviour of Wastes in Landfill-Leachate, Chapter 7; Behaviour of Wastes in Landfill-Methane Generation, Chapter 8., J. R. Holmes (Eds.) Practical Waste Management, John Wiley and Sons, Chister, England.

Pennington, D. W.; Koneczny, K., (2007). Life cycle thinking in waste management: Summary of European Commission's Malta 2005 workshop and pilot studies. Waste Manage., 27 (8), 592-597 (6 pages).

Pohland, F. G., (1987). Critical review and summary of leachate and gas production from landfills. EPA/600/S2-86/073, U.S. EPA, Hazardous Waste Engineering Research Laboratory, Cincinnati, OH.

Pohland, F. G., (1991). Fundamental principles and management strategies for landfill codisposal practices.

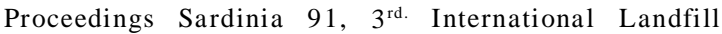
Symposium, 2 1445-1460., Grafiche Galeati, Imola, Italy.

Pré Consultants (2008). SimaPro 7, Amersfoort, The Netherlands.

Psomopoulos, C. S.; Bourka, A.; Themelis, N. J., (2009). Wasteto-energy: A review of the status and benefits in USA. Waste Manage., 29 (5), 1718-1724 (6 pages).

Stehlik, P., (2009). Contribution to advances in waste-toenergy technologies. J. Clean. Product., 17 (10), 919-931 (12 pages).

Tehrani, S. M.; Karbassi, A. R.; Ghoddosi, J.; Monavvari, S. M.; Mirbagheri, S. A., (2009). Prediction of energy consumption and urban air pollution reduction in e-shopping adoption. Int. J. Food, Agri. Environ., 7 (3-4), 898-903 (7 pages).

AUTHOR (S) BIOSKETCHES

Zaman, A. U., M.Sc., Environmental Engineering and Sustainable Infrastructure, School of Architecture and Built Environment, KTH, Sweden. Email: atique@kth.se

How to cite this article: (Harvard style)

Zaman, A. U., (2010). Comparative study of municipal solid waste treatment technologies using life cycle assessment method. Int. J. Environ. Sci. Tech., 7 (2), 225-234. 